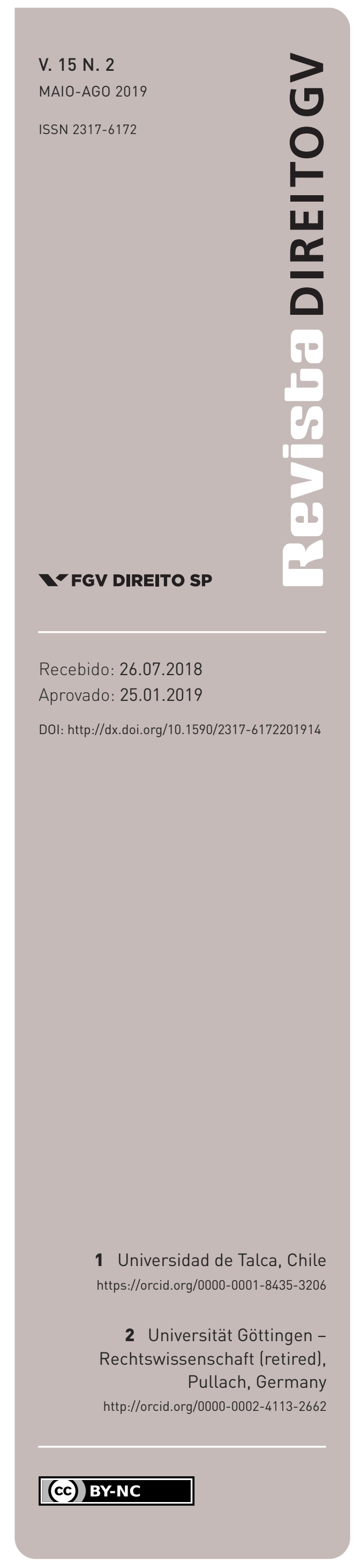

\title{
Alternative dispute resolution in family disputes in Europe and Chile: mediation
}

\author{
RESOLUC̦ÃO ALTERNATIVA DE LITÍGIOS EM CONFLITOS FAMILIARES NA EUROPA E NO \\ CHILE: MEDIAÇÃO
}

Carolina Riveros ${ }^{1}$ and Dagmar Coester-Waltjen ${ }^{2}$

\section{Abstract}

The purpose of this paper is to examine whether the issues in family mediation are similar in Europe and Chile. The use of mediation in the world represents a significant progress in protecting family agreements and their autonomy. We conclude that Europe and Chile have to pay special attention to the quality control mechanisms and training of the mediators in family disputes.

\section{Keywords}

Family law; mediation; mechanism; family dispute; agreement.

\section{Resumo}

O objetivo deste artigo é examinar se as questões sobre a mediação de família são semelhantes na Europa e no Chile. $O$ uso da mediação no mundo representa um progresso significativo na proteção de acordos de família e sua autonomia. Concluímos que a Europa e o Chile têm de prestar atenção especial aos mecanismos de controle de qualidade e ao treinamento dos mediadores em litígios de família.

\section{Palavras-chave}

Direito de família; mediação; mecanismo; litígio de família; acordo. 


\section{INTRODUCTION}

Mediation in family law matters (as in other matters of civil and commercial law) is defined as a structured process whereby two or more persons in a family dispute attempt to reach an agreement on their dispute by themselves, with the assistance of a mediator.

In contrast to judicial proceedings and other means of alternative dispute resolution for example arbitration - in mediation, it is not a judge or an arbitrator who finds the solution for the conflict, but the parties themselves. However, especially in family law, spouses may not divorce through a private agreement - at least in many judicial systems in Europe. In addition, the pursuit of the best interests of the children is seldom left to the parents alone. Their acts and decisions might need the approval of a court or might be subjected to a court decision. Thus, an agreement reached by the parties in the mediation process of a family dispute may not always be the end of the dispute itself, since there will be judicial proceedings before a family court or similar. Nevertheless, there are some issues in family law that the parties can agree with, out of any court intervention.

However, family mediation plays an important role in family disputes. Mediation can create a constructive atmosphere for discussion and preserve an amicable and sustainable relationship between the parties. This is especially important when there are children involved directly or indirectly. Mediation might be cost-effective, and often provide a quick extrajudicial solution to the dispute. Furthermore, parties might be inclined to comply willingly with the agreement, since they found the solution by themselves, and the arrangements might be especially tailored to the circumstances of their special case.

On the other hand, the highly emotional relationship between former intimate partners might cause enduring problems. Agreements might not be reached at all or may not last very long. In such cases mediation produces even more problems and offers neither a quick nor at least in many cases - a cost-effective solution. In addition, under the perspective of human rights and constitutional guarantees the right of the family members to access the judicial system has to be respected. The community (especially the courts) remain responsible for the wellbeing of family members, above all for the best interests of the children.

It is said that the same arguments for and against mediation apply to mediation in all legal disputes, not only on family matters. However, in family disputes both the positive and the negative aspects seem to be of special concern: on the one hand, it is necessary to soothe the atmosphere and the emotions of the conflicting family members, to help them find a peaceful solution; on the other hand, the extreme vulnerability of the persons involved, especially the children, could lead to an unreasonable decision-making process. Therefore, mediation in family disputes demands special safeguards and control.

\section{The Legal FrAMEWORK: EUROPE AND CHILE}

There are no unified rules directly applicable to family mediation in Europe. The UNCITRAL 
Model Law - besides being concerned only with international commercial disputes - has limited its influence over European legislation on mediation to some legal systems ${ }^{1}$ and to a certain extent.

In the context of the so-called "Malta Process"2 a working party has also drawn up principles for the establishment of mediation structures. ${ }^{3}$ Already in 1987 a special office was created for child abduction cases: The European Parliament Mediator for International Parental Child Abduction. ${ }^{4}$ There is also an European E-justice Portal providing information on the national mediation systems in family matters. ${ }^{\mathbf{5}}$

More important for a uniform approach has been the inclusion of the EU Directive 2008/52/EG on Certain Aspects on Mediation in Civil and Commercial Matters of May 21, $2008 .^{6}$ However, this does not provide a uniform law for all member states.

As the title already indicates, these rules are not confined to family disputes. But the recitals and the comments of the European Commission on that Directive stress the special need to offer mediation services and encourage its use, especially in family matters. Therefore, the rules of the Directive are designed in a way that the characteristics of family disputes can be considered.

As we know, the Directive only concentrates on some basic points and principles, such as the voluntary character of mediation, the independence, competence, impartiality and equidistance of the mediator, the fairness and confidentiality of the proceedings, the protection of rights during the mediation process (no limitation and prescription), access to legal advice, enforceability of agreements and access to court if mediation fails.

In addition, the Directive proposes mechanisms to further mediation by providing information on mediation systems and services, as well as encouraging mediation as an alternative to court proceedings. The Directive leaves the implementation of the named principles and proposals to national legislators.

By now, all member states have at least some rules on mediation, and many of them have a comprehensive legislative framework regulating mediation. Mediation and family disputes

1 See KNIEPER, 2011 (stressing the special interest in referring to the Model Law when enacting laws on mediation in Southeast Europe).

2 "A dialog involving contracting and non-contracting states to the Hague Abduction Convention and aiming at improving cooperation in cross-border family disputes involving children", see https://www. hcch.net/es/news-archive/details/?varevent $=349$.

3 See $\mathrm{HCCH}$, working party on mediation in the context of the Malta Process, principles for the establishment of mediation structures in the context of the Malta Process, November 2010.

4 See http://www.europarl.europa.eu/atyourservice/en/20150201PVL00040/Child-abduction-mediator.

5 See https://e-justice.europa.eu/content_crossborder_family_mediation-372-en.do.

6 OJ L136, 24.05.2008, p. 3. 
frequently receive special attention. Mediation seems to be used more often in family disputes than in other civil or commercial cases. This might be due to the conciliatory character of mediation, which is of additional importance to family law matters. ${ }^{7}$

Although the Directive focusses on cross-border mediation, many of the European states (24) have extended the cross-border mediation rules to domestic mediation proceedings. The rules vary, and only a few guidelines are provided for structures of mediation, leaving the task of arranging information and offering mediation services mostly up to non-governmental organizations. Thus, the legal situation within the European states is very heterogeneous. Therefore, we shall focus on some issues of family mediation that have attracted the special interest of some legislators in Europe.

In Chile a specific legal framework rules family mediation. ${ }^{8}$ According to Art. 103, mediation in Chile is: "that system of conflict resolution in which an impartial third party, without decision-making power, called a mediator, helps the parties to seek a solution to the conflict and its effects themselves, by means of agreements".

There are thus two essential elements of mediation, namely: the involvement of a third party and the responsibility of the parties in the decision-making process (OBREQUE; TOBAR, 2012, p. 163).

The basic principles in Chilean mediation are: equality, the voluntary character of mediation (CORREA, 2014, p. 114), independence, the impartiality and equidistance of the mediator, the fairness and confidentiality of the proceedings, the best interests of the children and third-party opinion (Art. 105 of Law n. 19.968 of 30.08.2004). Everything that the parties decide and agree on in the mediation process reflects directly on each member of the family. Therefore, a true application of "the best interests of the children" principle implies that all members of the family are benefited, not only adults (ALARCÓN, 2015, p. 17, 41). In short, it is a question of making decisions in matters that affect their own lives and their environment (VALDEBENITO, 2013, p. 59).

Comparatively speaking, the principle of the best interests of the children is more novel in Chile than in Europe.

\section{INFORMATION}

How do persons involved in a family dispute get information about mediation as a means to solve their conflict? In France, for example, there are the Association for Family Mediators

7 In Hungary 25 to 30 percent of all cases that get to a mediator are family mediation cases. The new rules on consumer mediation may make mediation attractive in that field of law also.

8 In Chile Arts.103-114 of Law n. 19.968 of 30.08.2004. (In 2008 Law n. 20.286 regulated family mediation in Title V of Law n. 19.968 and repealed the regulations on family mediation in Law n. 19.947). 
and the National Federation of Family Mediators Association - these are, among others, the two main non-governmental organizations -, that may be contacted and will provide a directory of mediation services. The same applies to Germany, where, among others, the Federal Association for Family Mediators will give advice. In England and Wales mediation is self-regulated, but a number of organizations have converged to form the Family Mediation Council in order to harmonize the standards and to deal with the government. In Spain, family mediation services vary between the different Autonomous Communities, sometimes the community itself, sometimes a local authority, sometimes private organizations may offer such services. In Austria, the Federal Ministry of Justice may be contacted. The same applies to Portugal, where a centralized government body is responsible for the regulation of mediation activities. ${ }^{9}$

In order to increase awareness of the possibilities, German law requires that in the first submission to the court, parties to family disputes have to state whether and why they did not considered mediation as a solution to their conflict. ${ }^{10}$ In England and Wales, it is a legal requirement that anyone applying to court for an order about their children attend a Mediation Information and Assessment Meeting (MIAM) beforehand. In some legal systems, the court itself must try conciliation in a preliminary hearing; in many of them, the court must invite the parties to mediation, ${ }^{11}$ or at least have them attend to informational sessions about mediation. ${ }^{12}$ Some legal systems also provide compulsory mediation in some or all family disputes. ${ }^{13}$ This is not seen as a violation of the principle of voluntariness of mediation stressed by Art. 3 of the Directive - as long as the parties still retain their right to access the judicial system if mediation fails, as per Art. 5 (2) of the Directive. The issue of obligatory mediation sessions, however, is very controversial. The majority of member states as well as academics oppose such a solution as it is contrary to the very essence of mediation and might be only costly and time-consuming.

In Chile, some characteristics of mediation include that the mediator may be appointed by the parties. Furthermore, the mediator must be registered in the Registry of Mediators. ${ }^{14}$

9 There are no non-governmental organizations working in the area of mediation in Portugal, but there are private associations which provide mediation services and train mediators.

$10 \S 23$ German Law on Family Proceedings.

11 France: Art. 22.1 Law of 8.02.1995, n. 95-125, as enacted by Ordinance n. 2011-1540 of 16.11.2011.

$12 \S 135$ German Law on Family Proceedings - in cases of divorce and consequences of divorce; $\S 156$ German Law on Family Proceedings in disputes concerning children; France: Art. 255, 373-2-10 Civil Code.

13 Croatia for all family disputes, Hungary for child custody issues.

14 Art. 112 and 113, Law n. 19.968 of 30.08.2004. According to Salazar (2016, p. 11), in 2016 there were 3.290 mediators in Chile and 85 percent were women. 
Mediation services shall be as a general rule free of charge, in respect to the matters of Art. 106 of Law n. 19.968 (maintenance, personal care and the right of parents to maintain a direct and regular relationship with their children).

\section{KINDS OF MEDIATION}

There are also differences in the available or regulated kinds of mediation in Europe. There is free mediation offered by non-governmental mediation services, there is court-annexed mediation, in-court mediation, and there are also mediative elements in the rules on family proceedings. Although the latter result in a departure from the contradictory character of civil procedural law, they have attracted some attention in the last decades. ${ }^{15}$ But this approach is extraneous to the European Directive (Art. 3 (a) (ss 2)). ${ }^{16}$ In-court mediation - which means mediation by another judge who is not responsible for any judicial proceeding concerning the dispute in question $-{ }^{\mathbf{1 7}}$ has become quite popular in Germany, ${ }^{18}$ although the German Law on Mediation (Mediationsgesetz) does not cover this kind of mediation. ${ }^{19}$ In several European states court-annexed mediation plays a special role in family disputes. This means that, with the consent of the parties, the court may suspend the proceedings and refer the case to a court-appointed mediator ${ }^{20}$ or to a mediator chosen by the parties from a list of mediators offered by the court, ${ }^{21}$ or to mediation as such leaving the choice of the

15 Especially in Germany, where procedural rules in family matters were reformed substantially in 2009. Even in the UK proceedings concerning children are less controversial today, see Family Procedural Rules. In Austria all proceedings concerning children are subject to the non-contradictory law (Außerstreitgesetz).

See also In-debt Analysis, the Mediation Directive, European Implementation Assessment, European Parliament Research Service, p. 21.

17 See also Art. 3 (a) (ss 2) Directive.

18 See $§ 36$ (5) German Law on Family Proceedings and $§ 278$ (5) German Code of Civil Procedure - except for divorce and nullification proceedings, 1113 (4) no. 4 German Law on Family Proceedings (because the spouses cannot dissolve their marriage by agreement; but the court may adjourn the proceedings if it sees a chance of reconciliation of the spouses, §136 German Law on Family Proceedings).

19 There was objection from several professional bodies offering mediation services to include this in-court mediation because it might prevent parties from looking for out-of-court mediation services. There has been objection also from the academic side, stressing that it is the paramount duty of the courts to decide disputes and not to leave it to the parties concerned.

20 France: Art. 131-1 Code of Civil Procedure (the court may allow only a certain time period for reaching a result).

France: Art. 22.1 Law of 2.02.1995, n. 95-125. 
mediators to the parties. ${ }^{22}$ In German law the parties to a family dispute always have the right to such adjournment if they want to try mediation independently of the judge's intention. However the court should at least see some chance for an amicable solution (§36a (2) German Law on Family Proceedings). ${ }^{23}$

The kinds of mediation in Chile are regulated in accordance to the topics with which the mediation is concerned, and these topics determine if the mediation is prior, compulsory, voluntary or forbidden. ${ }^{24}$ In Chile, prior and compulsory mediation must be carried out for the filing of claims in respect to maintenance, personal care and the right of parents to maintain a direct and regular relationship with their children.

Mediation is forbidden on matters relating to the marital status of persons (except for cases covered by the Marriage Act); declaration of interdiction; cases involving children and adolescents, and the procedures regulated by Law n. 19.620 on adoption.

The remaining matters of competence of the family courts may be subject to mediation if agreed on or accepted by the parties.

\section{Competence of THE Mediator}

All European member states require that mediators be competent to handle the dispute before them. But there is a great variety of rules on conduct, quality control mechanisms and training. Most states have adopted the European Code of Conduct for Mediators; however, this does not especially focus on family disputes, and contains rather broad principles. In order to assure a high quality of mediation, many legal systems establish a registration or accreditation procedure, some making accreditation obligatory, some defining a specific professional profile for mediators or restricting access to the profession. Many legal systems demand at least initial training and further education. For mediation in family disputes special training is obligatory in England and Wales, France and Luxembourg. Training courses are often run by non-governmental institutions, but might have to be approved by the Ministry of Justice, as is the case, for example, in Portugal. In Germany, unfortunately there are only a few restrictions on who may act as a mediator and no special rules for this profession. Until recently all of this was left to private engagement, organizations and the market. However, there is now at least a regulation on the training of persons who may call themselves "certified mediators". ${ }^{25}$ But there are no special rules for family mediation and the law only prescribes

$\S 36 a$ German Law on Family Proceedings.

23 Ulrich, MüKo-FamFG, Commentary on the Act on Family Proceedings, § 36a, note 13 a.e.

24 Art.106 Law n. 19.968 of 30.08.2004. Barcia, 2011, p. 363.

Regulation on the Training and Further Education of Certified Mediators of 21.08.2016, BGBl 2016 I 1994. 
that the mediator should have the relevant competence. ${ }^{26}$ Non-certified mediators may still act as mediators.

To be included in the Registry of Mediators in Chile, one must have a professional degree that is at least eight semesters in duration, granted by a state-run higher education institution or recognized by it; accredited specialized training in mediation and family matters or children, ran by a university or other institution, or by an institute that promotes teaching, training or research in such matters; and not have been convicted of an afflictive felony, for any of the offences referred to in Articles 361 to 375 of the Criminal Code, or acts that constitute domestic violence. The Registry of Mediators in Chile is administered by the Ministry of Justice and Human Rights. The provision of mediators in Chile is carried out through a bidding system (operational and technical conditions are fixed), and the quality of the mediator's offer is assured through this system. The quality requirements for family mediation in Chile have been provided by the Mediation Unit of this Ministry and especially by the quantitative instrument for evaluating the quality of family mediation (ECAME) (VALDEBENITO, 2017, p. 271-289).

The statistics provided by the Chilean Ministry of Justice for the period 2009-2014 show the following:

The majority of the cases of mandatory mediation are those concerning maintenance, which fluctuate between $62 \%$ and $63 \%$. An average of $26 \%$ of the cases concern visitation rights. A smaller number, $11 \%$, are related to personal care. However, other issues have not exceeded $1 \%$ in several years. Table 1 shows completed and failed cases.

\section{TABLE 1 - COMPLETED AND FAILED CASES}

YEAR

26 If the mediator does not have that competence and thereby causes damage to the parties, he or she might be held liable; of course there might be a problem of proof and causation, see for example the case of the OLG Stuttgart of 26.06.2017 affirmed by BGH of 21.09.2017, NJW 2017, 3442. 
2012

$40(48 \%)$

$59(52 \%)$

2013

$42(62 \%)$

$57(38 \%)$

2014

$43(18 \%)$

$56(83 \%)$

Source: Created by the authors based on data provided by the Chilean Ministry of Justice.

These numbers demonstrate that unsuccessful cases exceed the agreements reached between the parties through mediation. The high percentage of unsuccessful cases is mainly due to mediation being mandatory prior to court in the national system. Likewise, according to CORREA, in forensic practice, two types of mediators are distinguished: "mediators to mediate and reach an agreement" and "mediators not to reach an agreement". When people have a real interest in engaging in mediation to bridge their differences and participate in such a procedure, they turn to the mediators in the first group. On the other hand, if they are not interested in the mediation process and just want to be able to file a complaint, they will use the services of the second group. In any case, it should be pointed out that the act of frustrated mediation constitutes a requirement for the admissibility of a claim brought before the family courts in respect to matters subject to mediation.

\section{FAIRNESS OF THE PROCEEDINGS}

Trusting in the fairness of the mediation process is decisive for the parties as well as for the courts and other persons or institutions who will refer the parties to mediation. Therefore, the EU Code of Conduct for Mediators requires independence and impartiality of the mediator. Thus, he or she must not have any financial or other interest in the outcome of the mediation, nor any personal or business relationship with one or more of the parties. If the mediator or a member of his or her firm has acted in any capacity for one or more of the parties, this - as well as other circumstances that may give rise to a conflict of interest - has to be disclosed.

The mediator has to act impartially towards the parties and be committed to serving all parties equally. Although it seems to be a matter of course that a mediator must not take the position of one party, fairness of the proceedings might require that the mediator has to help level the playing field by a selective facilitation of the discussion. This principle, the so-called "equidistance", is especially important in family disputes, in which emotions may blind the conflicting family members. Thus, the mediators may indicate incompleteness of information, serious deviations from legal rules, and their concerns about the fairness of the result. He 
or she may support one party in the dispute over the other with the intention of establishing an equilibrium between them (see also 3.1 EU Code of Conduct). If children are involved, their rights also have to be respected by the mediator. This is definitely one of the most difficult tasks in mediation, and the mediator must be careful that he or she does not lose his or her neutrality nor appear to be biased.

There are additional safeguards. The mediator must insist that any agreement is reached by all parties through knowing and informed consent and that they all understand the terms of the agreement (Rule 3.3 EU Code of Conduct). He or she may withdraw from mediation in cases where the agreement seems totally unfair to him or her. Some legal systems provide that the parties should get independent legal advice before they sign a binding agreement. ${ }^{27}$

Finally, the parties taking part in a mediation proceeding should have the security that their rights will not perish during the attempt to settle, because of expiry of limitation or prescription periods (Art. 8 Directive). Thus, all member state laws provide for a suspension of these periods during the mediation process.

In Chile there is the principle of impartiality, which implies that the mediators shall be impartial in relation to the participants, and should refrain from promoting actions that compromise this condition. If such impartiality is affected by any cause, the mediators shall reject the case, justifying themselves in the appropriate court of law. Those involved may also request the appointment of a new mediator, when they can justify that the impartiality of the initial mediator is compromised.

The first session of the family mediation proceedings in Chile will begin with information to participants about the nature and objectives of mediation, the principles that inform it, and the legal value of any agreements they may reach.

The mediation process may not last more than sixty days. However, the participants, by mutual agreement, may request an extension of this period for another 60 days.

It is also important to highlight the role that children and adolescents play in Chile because of the impact that adults' decisions can have on their lives. The primary basis is the best interests of the children and also the right to be heard and the analysis of the children's ability to participate in mediation (ALARCÓN, 2015, p. 20, 24).

It is also important to ensure that children and adolescents are informed of the process and the results achieved. It is essential to explain to them that their participation does not make them responsible for the decisions their parents may make (CÓRDOVA; GONZÁLEZ; VALDEBENITO, 2012, p. 5; VALDEBENITO, 2017, p. 48-69). 


\section{Confidentiality}

Confidentiality is another essential characteristic of mediation as prescribed by the European Directive (Art. 7). Especially in family mediation, openness and trust play a crucial role. Neither the mediator nor anyone involved in the administration of the mediation process should be compelled to give evidence in civil judicial proceedings regarding information arising out of or in connection with the mediation. All member states have enacted the respective rules. ${ }^{28} \mathrm{~A}$ breach of confidentiality, however, may be legitimized if public policy or the interests of an otherwise endangered child require disclosure.

The Directive does not oblige the member states to hinder disclosure in criminal proceedings (for example in the case of child abuse) nor does it deal with non-disclosure by the parties themselves. Often at the beginning of the mediation the parties agree to keep the content of the agreement confidential as well as facts revealed during the mediation proceedings. However, they cannot avoid their duty to give testimony in a court proceeding. Thus, it is important that the mediator explain the limited concept of confidentiality to the parties.

In Chile the mediator is required to keep a record of everything he or she has heard or seen during the mediation process and this will be covered by professional secrecy. Violation of this reservation shall be punishable by the penalty provided for in Article 247 of the Penal Code. Nothing said by any of the participants during the course of the mediation may be invoked in any subsequent judicial proceeding. However, the mediator shall be relieved from the duty of confidentiality in those cases where he or she becomes aware of the existence of situations of mistreatment or abuse of children, teenagers or disabled people. In any case, they must make the meaning of this exemption known to the parties in advance.

\section{Mediation agreement}

Some, but not all mediation agreements can be made enforceable in Europe simply by having them sealed by a public notary ${ }^{29}$ or having them converted into a binding court consent order $^{30}$ or into a court-approved compromise. ${ }^{31}$ As far as a court is involved the court must be satisfied of the fairness of the agreement and may deny its approval if the agreement seems unfair or could impair the wellbeing of a child.

$29 \S 794$ German Law on Civil Procedure.

30 In England, possible for family disputes.

$31 \S 156$ (2) German Law on Family Proceedings. 
If the parties are not allowed to dispose of the issue - for example in divorce or marriage annulment proceedings ${ }^{32}$ or decisions on parental authority in case of separation, in some legal systems - mediation may still be sensible ${ }^{33}$ but the agreement reached during mediation cannot be made enforceable on these issues. A court decree has to be issued. However, the consent of the parties might help the court in deciding the case and the parties might be inclined to accept the judgment more easily.

In matters of which the parties may dispose - like many financial questions - mediation agreements should be declared enforceable on the application of the parties. In Europe they may be enforceable also in other member states. It should be mentioned that the Hague Conference seems to develop a new binding instrument in order to facilitate family agreements and their recognition and enforcement in the contracting states. ${ }^{34}$ This might make mediation even more attractive.

The mediation act in Chile approved by the judge has executive merit. The mediation act shall be forwarded by the mediator to the court for their approval on anything that is not contrary to the law, and the judge may in any case remedy any formal flaws in the case, respecting the will of the parties at all times expressed in the minutes. Approved by the judge, it will have the value of an executed sentence.

\section{CONCLUSION}

Amicable solutions and long-lasting agreements in family disputes are certainly welcome. In this sense mediation seems to be an appropriate tool to solve family conflicts. But despite the principles of the European Directive and the safeguards applied by the national laws in Europe and Chile, the success of mediation proceedings depends predominantly on their quality. This is the central issue. More could be done to enhance the training of mediators, especially with regard to their abilities to act in family disputes. For the time being, more scrutiny should be applied in controlling training programs, mediation services and contracts, as well as the procedures followed. This applies especially to German and Chilean law.

It is important to highlight, in this sense, the practices carried out by the Chilean administration system aimed at ensuring the quality of mediation services, in an exemplary manner:

32 In many European legal systems, a marriage can only be dissolved by court decree, not by a private act, although some European states have introduced private divorce recently.

33 In many cases of divorce, the spouses do not disagree on the divorce as such, but fight about the consequences of the divorce proceedings.

$34 \mathrm{HCCH}$ : Experts Group meeting on recognition and enforcement of agreements in family matters (1416 June 2017). 
the Mediation Unit of the Ministry of Justice and Human Rights and the evaluation of the quality of mediation (ECAME), among others.

In family disputes one should not leave the issues to the market, because in these matters market mechanisms are only effective to a lesser extent. If judges in family courts are trained not only in family law but also in communication and some psychological aspects, it seems to us that in-court mediation - i.e. a family court judge who is not responsible for any judicial proceeding in the relevant dispute - might be a preferable alternative to "free mediation services".

A change in the atmosphere in family courts in general seems to be very important to us. The contradictory character of the proceedings in family courts should be reduced. Amicable solutions by the people concerned should be encouraged even within judicial proceedings. Mediation might be one solution suitable for some cases, others might need another structure.

\section{ACKNOWLEDGMENTS}

The authors thank the financial support of the project Anillo Programa titled "Alternative Dispute Resolution Mechanisms as Tools for Modernizing Justice. A Dogmatic Construction from a Multidisciplinary Analysis", CONICYT, Chile.

\section{REFERENCES}

ALARCÓN, Miguel. Conveniencia de la participación de los niños en el proceso de mediación. Ars boni et aequi, año 11, n. 2, p. 11-47, 2015.

BARCIA, Rodrigo. Fundamentos del derecho de familia y de la infancia. Santiago de Chile: Puntolex Thomson Reuters, 2011.

CÓRDOVA, J.; GONZÁLEZ, I.;VALDEBENITO, C. Niños, niñas y adolescentes en la mediación. Bases de un modelo en construcción. In: VIII Foro Mundial de Mediación (I), Valencia, 2012. Memorias del [...], Valencia, 2012. p. 159-165. 
CORREA, Paula. La experiencia de la mediación familiar en Chile. Elementos para una política pública futura. Revista chilena de Derecho y Ciencia Política, v. 5, n. 2, p. 111-138, 2014.

KNIEPER, Judith. Mediationsgesetze in Südosteuropa. WiRo, p. 366, 2011.

OBREQUE, C.; TOBAR, J. La judicatura de familia. Santiago:Thomson Reuters, 2012.

ULRICH, Bernhard. MüKo-FamFG/Commentary on the Act on Family Proceedings. 2. ed, § 36a, note 13 a. e. 2013.

VALDEBENITO, Caterine. Presencia de los niños y niñas en la Mediación Familiar en Chile, Rumbos TS, añoVII, n. 7, p. 48-69, 2013.

VALDEBENITO, Caterine. Requerimientos de calidad en el ejercicio de la mediación familiar licitada en Chile. Reflexiones para su conceptualización. Polis, Revista Latinoamericana, n. 48, p. 271-289, 2017.

\section{COMO CITAR ESTE ARTIGO:}

RIVEROS, Carolina; COESTERWALTJEN, Dagmar. Alternative dispute resolution in family disputes in Europe and Chile: mediation. Revista Direito GV, v. 15, n. 2 , maio/ago. 2019, e1914. doi: http://dx.doi.org/10.1590/23176172201914.
Carolina Riveros

LAWYER. Ph.D IN LAW AT LUdWIG-MAXIMILIAN-UNIVERSITÄT MünChEn, Germany. LL.M. University of HeIdELBERG, Germany. Civil Law Professor at Talca University, Chile.

criverosautalca.cl

Dagmar Coester-Waltjen

Ph.D in Law at Kiel Universität, Germany. LL.M. UniVERSITY OF MICHIGAN, USA. CIVIL LAW, INTERNATIONAL Private LaW and Comparative Law Professor at Göettingen UNIVERSITY. SINCE 2012 SHE IS RETIRED.

coewalafreenet.de 